\title{
The reference range of serum, plasma and erythrocyte magnesium
}

\author{
Suzanna Immanuel, Anggraini Iriani
}

\begin{abstract}
Abstrak
Pengetahuan mengenai manfaat klinis kadar magnesium serum baru dimulai akhir-akhir ini seiring dengan adanya analisis dan penemuan bahwa kadar magnesium abnormal pada gangguan kardiovaskuler, metabolik dan neuromuskuler. Meskipun kadarnya di serum tidak menggambarkan kadar magnesium tubuh, tetapi saat ini yang dikenal luas penggunaannya hanya pemeriksaan kadar magnesium serum. Magnesium eritrosit saat ini dinilai lebih sensitif dari pada magnesium serum, karena magnesium eritrosit dapat mewakili penilaian status magnesium intrasel. Menurut NCCLS (National Committee for Clinical Laboratory Standards) setiap laboratorium dianjurkan memiliki nilai rujukan sendiri untuk pemeriksaan yang dikerjakannya, termasuk juga pemeriksaan magnesium. Nilai rujukan yang didapat sesuai dengan populasi dan dipengaruhi oleh metode serta teknik pemeriksaan. Penelitian ini bertujuan untuk mendapatkan nilai rujukan magnesium dalam serum dan plasma serta mendapatkan nilai rujukan magnesium intrasel yaitu magnesium eritrosit dengan metode pemeriksaan langsung dan mengetahui perbandingan hasil pemeriksaan antara magnesium serum dengan plasma. Bahan darah diambil dari 114 peserta donor darah di Unit Transfusi Darah Daerah (UTDD) Budhyarto PMI DKI Jakarta, terdiri dari 57 orang pria dan 57 orang wanita berusia antara 17-65 tahun, secara klinis sehat menurut kriteria donor darah PMI. Darah diambil dari selang blood set, langsung dimasukkan $4 \mathrm{~mL}$ ke dalam tabung vakum tanpa antikoagulan untuk pemeriksaan magnesium serum dan $3 \mathrm{~mL}$ kedalam tabung vakum dengan antikoagulan lithium heparin untuk pemeriksaan magnesium eritrosit dan plasma. Penetapan kadar magnesium dilakukan dengan alat kimia klinis otomatis Hitachi 912 dengan metode Xylidil Blue dengan prinsip kolorimetri.Pada penelitian ini didapatkan tidak ada perbedaan bermakna untuk hasil pemeriksaan magnesium ekstrasel memakai bahan serum maupun plasma heparin. Nilai rujukan untuk magnesium serum atau plasma adalah $1.30-2.00 \mathrm{mEq} / \mathrm{L}$ dan magnesium eritrosit adalah 4.46-7.10 mEq/L. (Med J Indones 2006; 15:229-35)
\end{abstract}

\begin{abstract}
The interest in the clinical importance of serum magnesium level has just recently begun with the analysis and findings of abnormal magnesium level in cardiovascular, metabolic and neuromuscular disorder. Although the serum level does not reflect the body magnesium level, but currently, only serum magnesium determination is widely used. Erythrocyte magnesium is considered more sensitive than serum magnesium as it reflects intracellular magnesium status. According to NCCLS (National Committee for Clinical Laboratory Standards) every laboratory is recommended to have its own reference range for the tests it performs, including magnesium determination. The reference range obtained is appropriate for the population and affected by the method and technique. This study aimed to find the reference range of serum and plasma magnesium and also intracellular magnesium i.e. erythrocyte magnesium by direct method, and compare the results of serum and plasma magnesium. Blood was taken from 114-blood donor from Unit Transfusi Darah Daerah (UTDD) Budhyarto Palang Merah Indonesia (PMI) DKI Jakarta, consisted of 57 male and 57 female, aged 17 - 65 years, clinically healthy according to PMI donor criteria. Blood was taken from blood set, collected into $4 \mathrm{ml}$ vacuum tube without anticoagulant for serum magnesium determination and $3 \mathrm{ml}$ vacuum tube with lithium heparin for determination of erythrocyte and plasma magnesium Determination of magnesium level was performed with clinical chemistry auto analyzer Hitachi 912 by Xylidil Blue method colorimetrically. This study showed no significant difference between serum and heparinized plasma extra cellular magnesium. The reference range for serum or plasma magnesium was $1.30-2.00 \mathrm{mEq} / \mathrm{L}$ and for erythrocyte magnesium was 4.46 - $7.10 \mathrm{mEq} / \mathrm{L}$. (Med J Indones 2006; 15:229-35)
\end{abstract}

Keywords: Reference range, extracellular magnesium, intracellular magnesium

Department of Clinical Pathology, Faculty of Medicine, University of Indonesia/Dr. Cipto Mangunkusumo Hospital, Jakarta, Indonesia
Magnesium (Mg) is the fourth most important cation in the body after sodium, calcium and potassium, and the second most abundant intracellular cation after potassium. Magnesium is mostly stored in bone, soft tissue and muscle. Less than $1 \%$ of body magnesium is found in extracellular compartment, with $0.3 \%$ of 
total body magnesium found in serum. Serum magnesium is present in 3 forms: $55 \%$ in the free form $\left(\mathrm{Mg}^{2+}\right)$, $30 \%$ binds with protein, especially albumin, and $15 \%$ forms complexes with phosphate, citrate, and other anion. ${ }^{1,2,3}$

Magnesium functions in the body physiological activity. Biochemical function of magnesium is synthesis and utilization of energy, i.e. ATP formation, transport of electron and proton, synthesis and activation of 300 enzymes, regulation of cell stability and maintenance of cell permeability through ionic pump. ${ }^{1,2}$ Thus, magnesium is an important component in regulation of cell.

The interest in the clinical importance of serum magnesium level has just recently begun with the analysis and findings of abnormal magnesium level in cardiovascular, metabolic and neuromuscular disorder. ${ }^{4,5}$ Although the serum level does not reflect the body magnesium level, but currently, only serum magnesium determination is widely used. ${ }^{3,5,6}$ Erythrocyte magnesium is considered more sensitive than serum magnesium as it reflects intracellular magnesium status.,

According to NCCLS (National Committee for Clinical Laboratory Standartds) every laboratory is recommended to have its own reference range for the tests it performs, including magnesium determination. The value obtained is appropriate for the population and affected by the method and technique.,

Determination of magnesium level can be done with various methods, i.e. titration, colorimetry/spectrophotometry, flame emission spectroscopy, atomic absorption spectrophotometry (AAS) and ion selective electrode (ISE). AAS is the reference method for magnesium determination. ${ }^{2,9}$ Intracellular (erythrocyte) magnesium determination can be done by 2 methods: indirect, and direct method. Indirect method measures magnesium level in whole blood and the hematocrit value is determined for calculation of intracellular magnesium. In the direct method, intracellular magnesium level is measured by lysing erythrocytes, such as done in this research. ${ }^{6}$

This study aimed to find the reference range of serum and plasma magnesium and also intracellular magnesium i.e. erythrocyte magnesium by direct method, and compare the results of serum and plasma magnesium.

\section{METHODS}

Blood was taken from 114-blood donor from Unit Transfusi Darah Daerah (UTDD) Budhyarto Palang Merah Indonesia (PMI) DKI Jakarta, consisted of 57 males and 57 females, aged $17-65$, clinically healthy according to PMI donor criteria. Blood was taken from blood set, collected into $4 \mathrm{ml}$ vacuum tube without anticoagulant for serum magnesium determination and $3 \mathrm{ml}$ vacuum tube with lithium heparin. Samples were immediately brought to laboratory to be tested in less than 2 hours after obtained.

Blood was centrifuged with the speed of $1200 \mathrm{~g}$ for 10 minutes to separate serum and plasma from blood cells, serum and plasma was decanted for determination of $\mathrm{Mg}$ level, while the remaining cells were lysed for the measurement of intracellular Mg level. ${ }^{7.10}$

Determination of magnesium level was performed by auto analyzer Hitachi 912 by Xylidil Blue method colorimetrically. ${ }^{6.11}$

\section{RESULTS}

Within run precision and accuracy of test using auto analyzer Hitachi 912 with Precinorm U and Precipath $\mathrm{U}$ as controls yielded CVs of $1.73 \%$ and $1.81 \%$, respectively, with deviations of $-0.55 \%$ and 0.84 .

Between day precision showed CVs of $2.21 \%$ with Precinorm U and $2.27 \%$ with Precipath U.

To determine serum, plasma and erythrocyte magnesium reference value, 114 samples from 57 male and 57 female donors were tested. Data was grouped according to gender, and each data group were tested for normality of distribution by Kolmogorov Smirnov test, and compared between groups. Serum magnesium levels of male and female group showed normal distribution (male $p=0.350$ and female $p=0.600$ ). Independent t-test showed no significant difference in serum magnesium of male and female $(p=0.176)$, so the serum magnesium data of both groups were joined. This data also showed normal distribution $(p=0.266)$, hence reference range was expressed as mean \pm 2 SD. Mean serum magnesium level in this study was $1.64 \mathrm{mEq} / \mathrm{L}$ with $\mathrm{SD}$ of $0.17 \mathrm{mEq} / \mathrm{l}$, and the reference range of serum magnesium was $1.30-1.98$ $\mathrm{mEq} / \mathrm{L}$. 
Plasma magnesium level from each gender group showed normal distribution (male $p=0.495$ and female $p=0.999)$. Independent t-test showed no significant difference in the plasma magnesium level between groups $(p=0.092)$. Data from both groups were joined, tested for distribution and showed normal distribution $(p=0.902)$. Mean plasma magnesium level was $1.66 \mathrm{mEq} / \mathrm{L}$, with $\mathrm{SD}$ of $0.17 \mathrm{mEq} / \mathrm{L}$, and the reference range of plasma magnesium obtained in this study was $1.32-2.00 \mathrm{mEq} / \mathrm{L}$.

Further, serum and plasma magnesium levels were compared, and t-test showed no significant difference between serum magnesium and plasma magnesium reference ranges $(p=0.108)$, which meant that plasma or serum can be used in the determination of magnesium level, ${ }^{9}$ reference range of which was 1.30 - $2.00 \mathrm{mEq} / \mathrm{L}$.

In the determination erythrocyte magnesium, each gender group showed normal distribution (male $p=0.520$ and female $p=0.593$ ) and independent t-test yielded no significant difference between erythrocyte magnesium of the groups $(p=0.190)$. Joined data showed a normal distribution $(p=0.210)$, with mean value of $5.78 \mathrm{mEq} / \mathrm{L}$ and $\mathrm{SD} 0.66 \mathrm{mEq} / \mathrm{L}$, thus reference range of erythrocyte magnesium obtained in this study was $4.46-7.10 \mathrm{mEq} / \mathrm{L}$.

\section{DISCUSSION}

Magnesium requirement of an adult male is 420 $\mathrm{mg} / \mathrm{day}$, and adult female is $320 \mathrm{mg} /$ day. In fact, this requirement is different according to age and gender., ${ }^{8,10}$ Dietary sources of magnesium are chlorophyllcontaining green vegetables, and legumes. ${ }^{11}$ Magnesium balance in the body is achieved rather slowly, because the half-life of radioactive-labeled magnesium varies from 41 to 181 days. $^{12}$

Hypomagnesaemia can be asymptomatic. Manifestations of hypomagnesaemia include irritability of central nervous system such as convulsion, muscle cramps, tremor, carpopedal spasm, cardiovascular disorders such as atrial fibrillation and tachycardia. Manifestation of hypomagnesaemia will occur if serum magnesium level is less than $1 \mathrm{mEq} / \mathrm{L}$. Conditions leading to hypomagnesaemia include alcoholism, malnutrition, lactating, malabsorption, chronic glomerulonephritis, cirrhosis and also prolonged intravenous feeding. ${ }^{13,14,15}$
Hypermagnesaemia is often encountered in renal failure or therapy with magnesium sulfate. Symptoms of hypermagnesaemia occur if serum magnesium level is higher than $4 \mathrm{mEq} / \mathrm{L}$, and is manifested in the form of depressed central nervous system functions such as lethargy, respiratory depression, loss of tendon reflexes, cardiovascular disorders such as bradycardia and conduction disorder. ${ }^{13,14,15}$

Although most of body magnesium comes from dietary intake, but the distribution regulation of magnesium according to proportion of intracellular and extracellular levels in various organ is not yet clear. Hormones are considered to play a part in of regulation of metabolism, including parathyroid hormone (PTH), anti diuretic hormone, calcitonin, glucagons and insulin. Parathyroid hormone responds to hypomagnesaemia by increasing intestinal absorption, increasing tubular reabsorption of magnesium and cellular uptake. Calcitonin and anti diuretic hormone $(\mathrm{ADH})$ regulates urinary excretion of magnesium. ${ }^{4.16}$

Electrolyte measurement, including the measurement of magnesium, consists of pre-analytical, analytical and post analytical phases. Pre-analytical phase includes patient preparation, blood collection, preparation of sample containers, transport and storage of sample. Analytical phase includes the type of reagents used and the assay method, while the post analytical phase comprises of reporting and recording of results. ${ }^{7.10}$

In the pre-analytical phase, blood sample for magnesium determination should not be taken after prolonged tourniquet application. ${ }^{9,19}$ Specimens recommended for the determination of magnesium are serum, heparinated plasma and urine..$^{2,7,10,17}$ The anticoagulant heparin is available commercially in the forms of sodium-, lithium-, ammonium-, zinc-, calsium-titrate or electrolytebalanced heparin. Heparin concentration should not exceed $10 \mathrm{IU} / \mathrm{mL}$. Heparin can be used in the form of liquid or powder. If aqueous heparin is used, hence the dilution factor must be considered, but this dilutional effect can be minimized by minimizing the ratio of anticoagulant to blood so that the effect becomes insignificant. Lithium heparin is the recommended anticoagulant for electrolyte determination and is the standard anticoagulant for blood gas analysis. ${ }^{718}$ In this study, for the determination of plasma magnesium, vacuum tube sprayed with lithium heparin was used. ${ }^{19}$ After blood was collected into the vacuum tube containing anticoagulant, the tube was shuffled several times to ensure homogenous mixing of blood and anticoagulant. ${ }^{10}$ 
Blood samples were then transported in a closed container to avoid contamination and evaporation, and then sent to the laboratory in upright position and room temperature $\left(18^{0}-28^{\circ} \mathrm{C}\right)$. Samples were centrifuged for 10 minutes at $1200 \mathrm{~g}$ to separate plasma from cells, and serum from clot. ${ }^{10}$ Hemolyzed samples are useless for the determination of serum magnesium level, as they will yield false high results due to intracellular magnesium release; serum magnesium level will increase $0.1 \mathrm{mEq} / \mathrm{L}$ for each $\mathrm{g} / \mathrm{L}$ hemoglobin released in the hemolytic process. ${ }^{7}$ Serum separation from cell sediment should be done immediately because of higher erythrocyte magnesium level. Decanted serum or plasma can be stored at $2^{0}-8^{0} \mathrm{C}$ for 1 week or at $-18^{0} \mathrm{C}$ for 1 month prior to determination. ${ }^{17,19}$

Reference method for magnesium level determination is AAS. ${ }^{2,9}$ Though it has high accuracy and precision, AAS is seldom used in the laboratory, as it requires very careful maintenance, calibration and sample preparation. $^{2}$

The method that is often used in the laboratory is colorimetry. This method use metalochromic indicator or dye, which will selectively bind magnesium and produce a color change. Some frequently used chromophores are calmagite, carboxalinido (xylidil blue), methylthymol blue, formazan dye, titan yellow and magon. ${ }^{2}$ This study used xylidil blue with chemistry autoanalyzer Hitachi 912.

Magnesium forms purple-colored complex with xylidil blue (diazonium salt) in alkaline environment. Calcium effect was eliminated with the addition of EGTA (etilen bis-oxyetilenenitrilo tetraacetic acid) buffer. ${ }^{17,19}$ Magnesium concentration is then measured by measuring the absorbance of colored complex by photometry method. Both free and protein-bound magnesium in the sample will react with dye xylidil blue, with stronger affinity between magnesium with dye compared to protein. ${ }^{18,20}$ The color produced is proportional to the complex formed and reflects magnesium level in sample. The reaction is described as following:

$$
\begin{aligned}
& \mathrm{Mg}^{2+}+\mathrm{Ca}^{2+} \underset{\text { chelator }}{\longrightarrow} \mathrm{Mg}^{2+}+\mathrm{Ca}^{2+} \text {-chelator complex } \\
& \mathrm{Mg}^{2+}+\text { xylidil blue dye } \underset{\text { alkaline } \mathrm{pH}}{\longrightarrow} \mathrm{Mg}^{2+} \text {-dye complex }
\end{aligned}
$$

Color change is measured at bichromatic wavelength of $600 \mathrm{~nm}$ and secondary wavelength of $505 \mathrm{~nm}$. Measurement at secondary wavelength $505 \mathrm{~nm}$ aims to eliminate extrinsic factors, sample color, etc. Calculation of magnesium level is by multiplication of the difference in the absorbance at $\lambda 600 \mathrm{~nm}$ dan $\lambda$ $505 \mathrm{~nm}$ by factor $\mathrm{K}$ from calibration. ${ }^{19}$

Determination of intracellular magnesium level can be done by 2 methods: direct and indirect method. Indirect method measured total blood magnesium (whole blood), serum magnesium serum and hematocrit (Hct). Calculation of intracellular magnesium is according to the following formula: ${ }^{20}$

Erythrocyte $\mathrm{Mg}=\left(\right.$ total blood $\mathrm{Mg}-$ plasma Mg) $\times \frac{(100-\mathrm{Hct})}{100} \times \frac{100}{\mathrm{Hct}}$

Mistake yielded by this method is quite substantial due to the number of parameters concerned in the calculation. Wallach S, Cahill LN, Rogan FH, et al. in their research compared the determination of erythrocyte magnesium with direct and indirect method, and reported that erythrocyte magnesium level determined with indirect method was in fact $0.6 \mathrm{mEq} / \mathrm{L}$ higher. ${ }^{20}$

In this study, intracellular erythrocyte magnesium was determined with direct method. To obtain intra-erythrocyte magnesium, erythrocytes were lysed prior to determination using a commercial hemolysate reagent available to quicken cell lysis. $^{6}$

Prior to research, pipettes used were calibrated. The calibration of semiautomatic pipettes yielded deviations of $-0.13 \%$ for the $100 \mathrm{uL}$ pipette and $0.84 \%$ for the $200 \mathrm{uL}$ pipette. The deviation value permitted is $<1 \%$. ${ }^{1}$

Result of within run precision with control material Precinorm U and Precipath U showed CVs of 1.73\% and $1.81 \%$. Within run precision specified by reagent manufacturer (Roche) using control material Precinorm $\mathrm{U}$ and Precipath $\mathrm{U}$ had CVs of $0.8 \%$ and $0.7 \%$, respectively. ${ }^{20}$ Laksman $S$. in her research reported $\mathrm{CVs}$ to control material Precinorm $\mathrm{U}$ and Precipath $\mathrm{U}$ of $4.1 \%$ and $4.2 \%,{ }^{21}$ while Kosasih AS reported CVs of $1.6 \%$ and $1.7 \% .^{22}$ Other study using Vitros reagent with normal control serum yielded $\mathrm{CV}$ of $1.4 \% .^{17}$ 
Table 1. Reference ranges for Magnesium in healthy humans

\begin{tabular}{|c|c|c|c|c|c|c|c|}
\hline No & Researcher & Years & $\Sigma$ & Method & Instrument & Reagent & $\begin{array}{l}\text { Reference Ranges } \\
\quad(\mathrm{mEq} / \mathrm{L})\end{array}$ \\
\hline 1. & Roche $^{19}$ & 2000 & & $\begin{array}{l}\text { Colorimetric } \\
\text { (Xylidil blue) }\end{array}$ & Hitachi 912 & Roche & $\begin{array}{c}1.3-2.1 \\
\text { (serum/ plasma) }\end{array}$ \\
\hline 2. & Milart \& Durlach ${ }^{6}$ & & 288 & ASS & Vitros 250 & & $\begin{array}{c}3.64-5.56 \\
\text { (erythrocyte) }\end{array}$ \\
\hline 3. & Vitros $^{17}$ & & & $\begin{array}{c}\text { Colorimetric } \\
\text { (formazanedyne) }\end{array}$ & Data Pro & Vitros & $\begin{array}{c}1.3-1.9 \\
\text { (serum) }\end{array}$ \\
\hline 4. & Thermo Trace ${ }^{8}$ & & & Colorimetric & & Thermo Trace & $\begin{array}{c}1.36-2.14 \\
\text { (serum/plasma }\end{array}$ \\
\hline 5. & $\begin{array}{l}\text { Carubelli, Smith, } \\
\text { Hammarsten }^{25}\end{array}$ & 1958 & 13 & $\begin{array}{l}\text { Spectrofotometric } \\
\text { titration erythrocyte } \\
\text { (not direct method) }\end{array}$ & & & $\begin{array}{c}1.55-2.06 \text { (plasma) } \\
4.69-5.86 \\
\text { (erythrocyte) }\end{array}$ \\
\hline 6. & Orange, Rhein ${ }^{25}$ & 1958 & & $\begin{array}{l}\text { Spectrofotometric } \\
\text { (titan yellow) }\end{array}$ & & TCA & $\begin{array}{c}4.45-5.59 \\
\text { (erythrocyte) }\end{array}$ \\
\hline 7. & $\begin{array}{c}\text { Wallach S, } \\
\text { Cahill LN }\end{array}$ & 1962 & 77 & $\begin{array}{l}\text { Spectrofoto metric } \\
\text { (direct method) }\end{array}$ & Shimatzu & TCA & $\begin{array}{c}1.75-2.34 \text { (plasma) } \\
4.3-6.4 \\
\text { (erythrocyte) }\end{array}$ \\
\hline 8. & This Study & 2004 & 114 & $\begin{array}{l}\text { Colorimetric (Xylidil } \\
\text { blue) erythrocyte. } \\
\text { Direct method }\end{array}$ & Hitachi 912 & Roche & $\begin{array}{c}1.3-2.0 \\
\text { (serum/plasma) } \\
4.46-7.10 \\
\text { (erythrocyte) }\end{array}$ \\
\hline
\end{tabular}

Between day precision using control material Precinorm $\mathrm{U}$ and Precipath U yielded CVs of $2.21 \%$ and $2.27 \%$. Between day precision specified by reagent manufacturer (Roche) with control material Precinorm $U$ and Precipath U showed CVs of $1.6 \%$ and $2.6 \% .^{19}$ Kosasih AS reported CVs of $2.0 \%$ and $1.7 \% .^{22}$ Other research using Vitros reagent showed between day $\mathrm{CV}$ to normal control of $2.3 \% .{ }^{17}$ Within run and between run precision testing in this research showed $\mathrm{CV}$ values comparable to those from other researchers, although there was no recommendation for $\mathrm{CV}$ for the test.

The reference range of serum or plasma magnesium obtained in this research was $1.30-2.00 \mathrm{mEq} / \mathrm{L}$. The reference range recommended in reagent kit insert from Roche (quoted from Tietz) for serum/plasma was 1.3-2.1 mEq/L, ${ }^{19}$ reference range of serum magnesium with Vitros was $1.3-1.9 \mathrm{mEq} / \mathrm{L},{ }^{17}$ whereas Thermotrace specified reference range of serum/plasma of 1.36$2.14 \mathrm{mEq} / \mathrm{L}{ }^{8}$ David $\mathrm{S}$ reported serum magnesium reference range of $1.24-1.9 \mathrm{mEq} / \mathrm{L}^{12}$ The reference range of serum and plasma magnesium level obatained in this research did not differ from other references
(Table 1). In some studies that have been done, the reference value of serum and plasma magnesium were not differentiated. ${ }^{2,9,15}$ Statistical test used in this research showed that there were no difference between the reference value of serum and plasma magnesium levels, so that serum or heparinated plasma may be used for the determination of extracellular magnesium level.

Determination of serum magnesium level is not a good method to assess magnesium status, because extracellular magnesium amounts to only $<1 \%$ of total body magnesium, hence serum magnesium level does not always reflect the actual amount of body magnesium. ${ }^{1,2}$ It is known that $30 \%$ of serum magnesium was protein-bound; if the serum protein level is altered, serum magnesium level will also be influenced. ${ }^{3}$ Serum magnesium will not fall below 1 $\mathrm{mEq} / \mathrm{L}$ until at least $25 \%$ of intracellular magnesium is lost, ${ }^{9}$ which means that low serum magnesium level generally shows a terminal magnesium deficiency. ${ }^{23}$ Considering $99 \%$ of body magnesium is in the intracellular compartment, it is important to assess the status of intracellular magnesium. ${ }^{23}$ 
Determination of erythrocyte magnesium is a relative simple way to assess intracellular magnesium. Magnesium levels in nucleated red blood cells (RBC) and reticulocytes are higher than mature erythrocyte. ${ }^{6}$ Animal research by Chollet concerning the relationship between total serum magnesium, serum free magnesium ion, erythrocyte magnesium, and intracellular magnesium of brain tissue showed significant correlation between serum free magnesium ion and erythrocyte magnesium, and intracellular magnesium of brain tissue. ${ }^{24}$ Considering that erythrocyte magnesium level is a more accurate reflection of body magnesium, in this research besides determining reference range of serum and plasma magnesium, we also determined reference value of erythrocyte magnesium.

Reference range for erythrocyte magnesium obtained in this research was $4.46-7.10 \mathrm{mEq} / \mathrm{L}$. Tietz reported erythrocyte magnesium level of $3.4-5.3 \mathrm{mEg} / \mathrm{L}$. Carubelli, Smith and Hammarsten in their research measured the erythrocyte magnesium with indirect method and reported reference range of 4.69-5.86 $\mathrm{mEq} / \mathrm{L} .{ }^{25}$ Orange and Rhein with titan yellow method obtained erythrocyte magnesium value of 4.45-5.59 $\mathrm{mEq} / \mathrm{L} .^{25}$ Milart and Durlach in their research using AAS method by direct determination reported erythrocyte magnesium level of 3.64-5.56 mEq/L. ${ }^{6}$ Reference value of erythrocyte magnesium in this research differed a little compared to some references (Table 1). This was probably caused by the difference in population and also the method and assay technique. ${ }^{7,8}$

Determination of serum/plasma magnesium is still requested a lot by clinician to assess body magnesium status in a sickness and also to monitor magnesium therapy. ${ }^{3}$ With the determination of intracellular erythrocyte magnesium level, it is expected that body magnesium status assessment can be as close to actual body magnesium condition as manifested by clinical condition. We hope that this determination can be utilized in the future.

\section{CONCLUSION}

Determination of reference range for serum, plasma and erythrocyte magnesium level in this research was done with xylidil blue method using Hitachi 912 colorimetrically. Determination of erythrocyte magnesium used direct method. Specimens for determination were heparinated plasma and serum from 114 healthy donors consisted of 57 males and 57 females. There was no significant difference between results of extracellular magnesium levels in plasma and serum, hence serum and also heparinated plasma can be used for assessment of extracellular magnesium level. Reference value for the serum or plasma magnesium was $1.30-2.00 \mathrm{mEq} / \mathrm{L}$ and erythrocyte magnesium was $4.46-7.10 \mathrm{mEq} / \mathrm{L}$.

\section{REFERENCES}

1. Polancic JE. Electrolytes. In: Bishop LM, Engelkirk JLD, Fody EP. Chemical Chemistry Principles, Procedure Correlations. $4^{\text {th }}$ ed. Philadelphia: Lippincott Williams \& Wilkins; 2000. p. 306-10.

2. Henry JB. Clinical Diagnosis and Management by Laboratory Methods. $20^{\text {th }}$ ed. Philadelphia: WB Saunders; 2001. p. 197-9.

3. Fawcett WJ, Haxby EJ, Male DA. Magnesium: Physiology and Pharmacology. British J of Anast. 1999; 83 (2): 30220.

4. Durlach J. Magnesium in Clinical Practice. The Magnesium Web Site Online Library. Avaiable at:http://www.mgwater.com/durex01.shtml.

5. Dacey MJ. Endocrine and Metabolic Dysfunction Syndromes in Critically III Hipomagnesemic Disorder. Critical Care Clinics. 2001. 17(1).

6. Milart H, Durlach V, Durlach J. Red Blood Cell Magnesium Concentration: Analytical Problems and Significances. The Magnesium Web Site. Magnesium Research (Review Paper). 1995; 8(1): 65-76. Available at: http://www.mgwater.com.

7. Moran RF, Bergkuist C, Graham GA, Misiano DR, O'Connell K, Sena SF. Consideration in The Simultaneus measurement of Blood Gases, Electrolytes and Related Analytes in Whole Blood; Proposed Guidelines. NCCLS C32-P. 1993; 13 (17). p.1-20.

8. Leaflet. Magnesium Reagent Calmagite Method. Thermo Trace. Australia. April 2002.

9. Tietz NW. Text Book of Clinical Chemistry. Philadelphia: WB Saunders; 1986. p. 971-5.

10. Anderson JJB. Minerals. In Malan LK, Strump SE eds. Krausse' Food Nutrition and Diet Therapy. Philadelphia. WB Saunders. 2000. p. 110-335.

11. Linder MC. Nutrition and Metabolism of the Major Minerals. In: Linder MC ed. Nutritional Biochemistry and Metabolism with Clinical Aplications. New York. Elsevier. 1985. p.133-6.

12. Marshall WJ. Illustrated Textbook of Clinical Chemistry. Philadelphia. JB Lippincott. 1989.189-206.

13. Schultz NJ, Slaker RA. Electrolyte Homeostasis. In: DiPiro JT, Talbert RL, Yee GC, Matzke GR, Wells BG, Posey LM eds. Pharmacoterapy A Pathophysiologic Approach. $4^{\text {th }}$ ed. Connecticut. Appleton \& Lange.1999. p.890-912.

14. Walmsley RN, Watkinson LR, Cain HJ. Cases in Chemical Pathology A Diagnostic Approach. $4^{\text {th }}$ ed. Singapore. World Scientific.1999. p. 110-6.

15. Worthley LIG. Synopsis of Intensive Care Medicine. London. Churchill Livingstone. 1994. p.264-475. 
16. Zilva JF, Pannall Pr. Clinical Chemistry in Diagnosis and Treatment. $4^{\text {th }}$ ed. Singapore. PG Publishing. 1987. p. 274-7.

17. Leaflet. Instructions for Use Vitros Chemistry Products Mg Slides. Version 2. England. Ortho Clinical Diagnostic. Desember 2002.

18. D'Orazio P, Miller WG, Myers GL, Doumas BT, Eckfeldt JH, Evans SA, et al. Standarization of Sodium and Potasssium Ion-Selective Electrode Systems to the Flame Photometric References Method; Approved StandartSecond Edition. NCCLS C29-A2. 1998; 20 (17). P. 1-21.

19. Leaflet. Magnesium. Germany. Roche Diagnostic. October 2000.

20. Wallach S, Cahill LN, Rogan FH, Jones HL. Plasma and Eritrocyte Magnesium in Health and Disease. J of Lab and Clin Med; 1962: 59(2). p. 195-210.
21. Laksman S. Kadar Magnesium Darah Pada Penderita Gagal Ginjal Kronik Serta Pengaruh Hemodialisis Terhadap Kadar Magnesium Darah. Jakarta. Departemen Patologi Klinik FKUI-RSCM. 1985.

22. Kosasih AS. Pola Kadar Magnesium Plasma dan Eritrosit serta Kalium Pada Infark Miokard Akut. Tesis dibacakan di Departemen Patologi Klinik FKUI-RSCM. 1991.

23. Magnesium Health Education. Library Pulication 1998. Up Loaded at july 24th 2002. Available at: http://www.naturalhealthnotebook.com

24. Chollet D. Blood and Brain Magnesium in Inbred Mice and Either Correlation with Sleep Guality. Am J Physiol. 2000; 279: 173-8. Available at: http://www.ajpregu.org

25. Carubelli R, Smith WO, Hammarsten JF. Determination of Magnesium in Erytrocytes. J of Lab \& clin path.1958; 51(6). 964-7. 